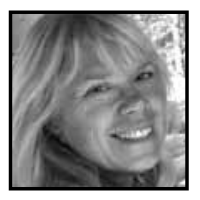

\title{
Museum Art in Everyday Life
}

\author{
Corrine E. Glesne
}

\begin{abstract}
Art museums engage diverse audiences in multiple forms of learning. Based on qualitative research at seven academic institutions, this article focuses on the role academic art museums play in the everyday life of students and faculty, on how people become interested in art and art museums, and on possible contributions of campus art museums beyond use in classes and research.
\end{abstract}

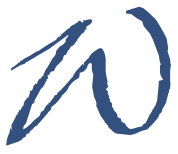
ith art museums or exhibition galleries included in at least 700 academic institutions in the United States (Russell \& Spencer, 2000), the academic art museum contributes to the formal education of many. Art museum educators reach out to children in public schools and develop programs for the college or university. Increasingly, museums also hire an academic curator or educator to assist faculty across the disciplines in incorporating art into teaching, assignments, and research (Goethals \& Fabing, 2007; Villeneuve, 2007). Less recognized is the role of campus art museums in informal education, in contributing to the everyday lives of people. This article focuses on such contributions.

Sponsored by the Samuel H. Kress Foundation, this study involved interviews and observations at seven colleges or universities, identified as having exemplary art museums. ${ }^{1}$ Each museum had received a Kress Study Collection ${ }^{2}$ around fifty years ago, but the institutions varied widely on indicators such as private/public, large/small campus populations, and rural/urban locations. One hundred twentynine people were interviewed, including students, faculty, museum directors and staff, campus administrators, and others such as security staff and community volunteers. 
When the opportunity to inquire into the ways in which exemplary art museums are integrated into campus life arose, I was intrigued. I am neither an artist nor an art historian. I have never worked in a museum nor taken classes in museum studies. Yet, I am a firm believer in the necessity for each of us to link with some form of creativity and as the study unfolded, I became a champion of multiple creative possibilities associated with academic art museums. As I listened to professors across the disciplines-language, history, literature, biology, math, business, and moredescribe ways in which they used the art museum in their classes, I was chagrined that I had never considered such options during my seventeen years as a university professor, other than to take a class or two to a relevant exhibit. The ways in which the art museum is used in academic classes is a topic for another article. The focus here on informal learning matters as well because, as interviewees told me, what's important is "getting them through the door." Then the art and didactics become the educators and muses.

This article begins with descriptions of the roles art museums can fill, other than use in teaching and research. Nearly three-fourths of study participants were involved in the arts-teaching, studying, or working at art museums. Many of those remaining interacted in some way with art museums. The second section, therefore, focuses on how interviewees became engaged with art and art museums. The third section attends to how participants talked about what art and art museums mean for their lives. This article concludes with thoughts about what having a campus art museum may contribute to an institution and the people who study and work there. 


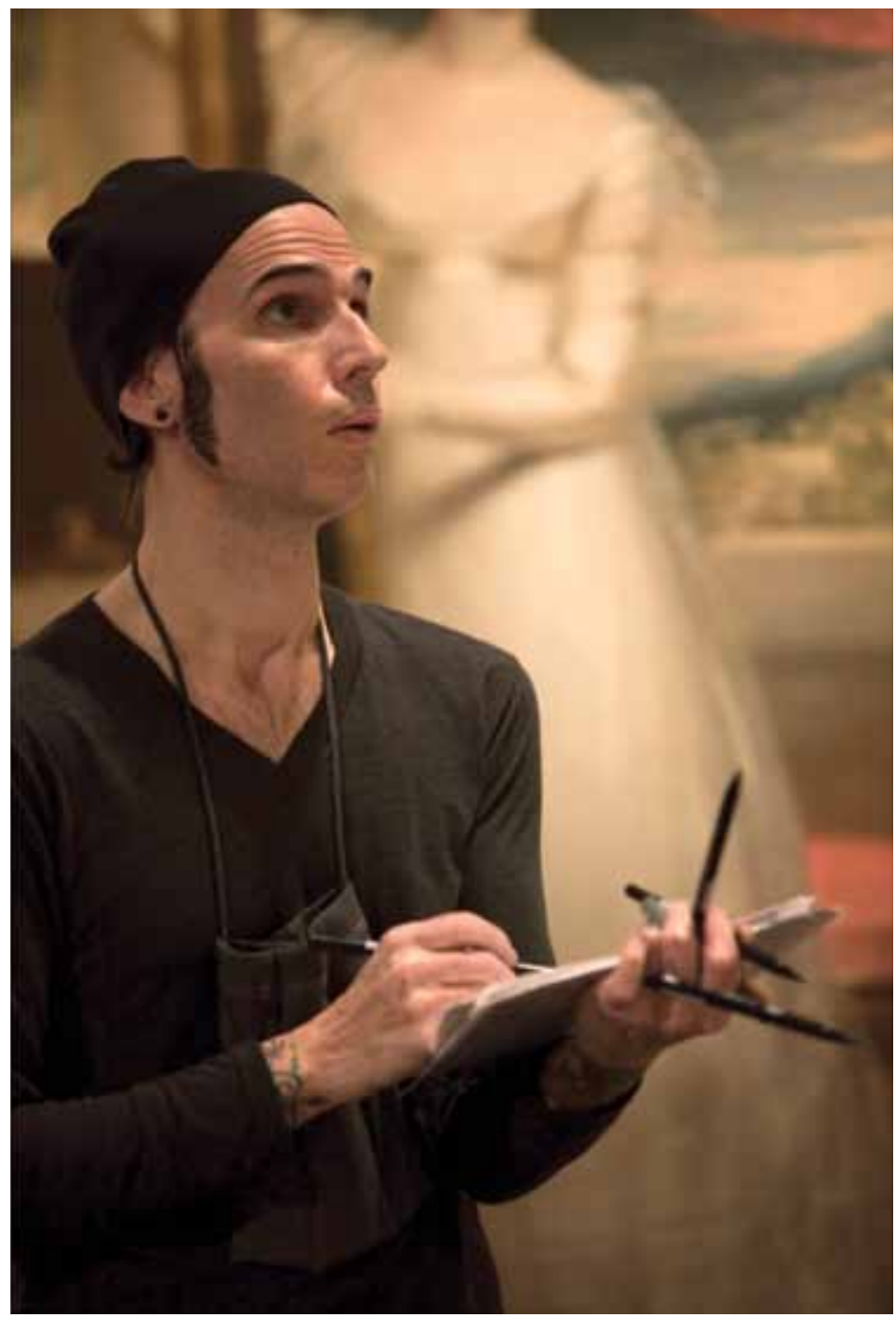

Fig. 1: Ernesto

\section{Engaging Beyond the Classroom}

A thin, wiry man stood in front of a painting, clasping a clipboard with a clump of recycled paper in his left hand. He stood still in meditation and then began to sketch rapidly. He placed his sketch on the floor below the painting and moved 
on to the next where he meditated and sketched again. I followed, looking first at the sketch on the floor and then up at the art work to find the details he had captured. Then, I found myself looking first at the painting and thinking what I would choose to document if I were the performance artist. Only then did I compare the image in my mind with that on the floor. I learned later that others did the same. For an entire day, from opening to closing, Ernesto Pujol documented the art on view within the Spencer Museum of Art. He did so silently, without a break, leaving a trail of drawings in a performance he called "Visitation." His work was a catalyst for others to dialogue, without words, with museum art and artist - visitors were welcomed to make their own sketches and leave them on the floor. Inspiring a fresh look at the art in the galleries, Pujol, at the end of the day, backed out of the museum and bowed in meditation as museum staff closed the doors. (Field notes, March 15, 2011)

Art museum staff trust the power of intrinsic motivation, of people's ability to learn through individual interests when engaged. One museum director said, "I'm a firm believer that the best education is actually self-education....engage students to be so compelled by something that they will follow up. So, the real issue is to get them in the door and get them in to look" (Personal communication, November 3, 2011). "It's about getting students into the museum," stated a student. "Once you see one thing in the museum, you want to see another thing. It's kind of like a contagious type thing" (Personal communication, November 5, 2010). Once people visit museums, they tend to return. They make use of the museums on their own, taking friends and guests, or seeking refuge when a quiet space is needed.

\section{Finding Solace and Inspiration}

Upon entering the University of Arizona Museum of Art, I walked up the stairs and saw to my right a wide doorway with gold lettering above it: "The Samuel H. Kress Collection The Altarpiece from Ciudad Rodrigo." The lighting and color of the steel blue room made the twenty-six large panels from the Fifteenth Century altarpiece of the Cathedral of Our Lady of the Ascension in Rodrigo, Spain virtually glow. In other galleries, visitors tend to enter and immediately go from one painting to the next, reading labels and studying the work. Here, they come in and stop, their eyes spanning the walls of the room, taking it all in, as one would do upon entering a basilica or great architectural space. Then, they go from one panel to the next, voices lowered to whispers. It's a place of reverence, reflection, and learning. As a student described: 
When you walk into that space and you see the religious art and the figures, it's just, you feel like, oh, like wow, this is very beautiful.... My favorite thing... is Friday afternoons, they have guitar playing and that is amazing... They have chairs in the Kress Gallery and everyone sits in it, there are so many people sometimes that they're standing, and the guitarists play and it's really amazing. (Field notes, January 26,2011 )

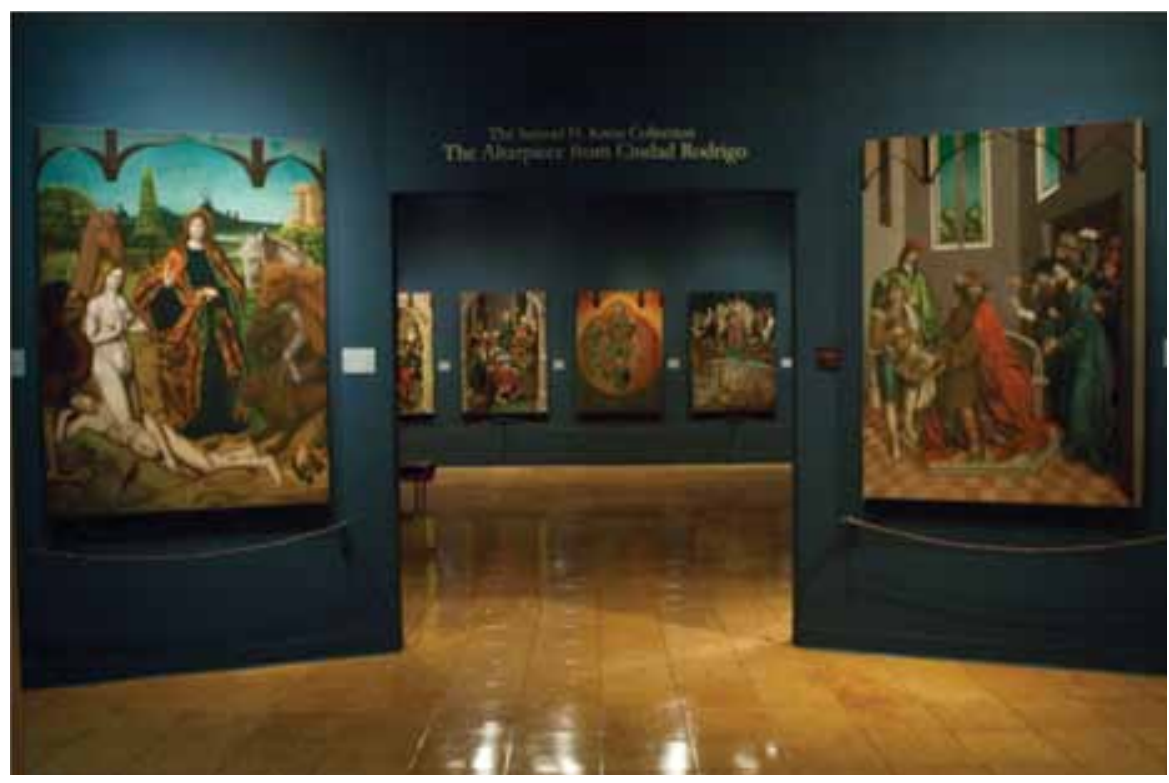

Fig. 2: Retablo entrance

Some faculty and students liken particular works of art to "family" and say that whenever they have a few minutes, they visit. A professor in the sciences said, "I have a favorite gallery. There's a painting up there that's my favorite in this building and if I've got five minutes, I'll go up and say 'hello'"' (Personal communication, March $15,2011)$. When art history or studio art departments are located near the museums, students frequently visit over class breaks, as one undergraduate described: "I'll come up for ten minutes and just go look at something I like." This student talked about how seeing things in the museum led her to want to know more and so she would use particular pieces in assignments: "I've seen things that I like that because I like them, I've used them in papers, but I liked them like months before I've gotten an assignment and so when I've got the assignment, I've used them" (Personal communication, March 15, 2011). A graduate student spoke about how he visited the campus art museum as a way to unwind, but in the process, he would become inspired: "I feel 
it is a release to come here and just relax and to look at other people's prints rather than work on my own. I feel it really helps me process how I want to further my own work, my own education by looking at these material objects that are collected here" (Personal communication, March 16, 2011).

The campus art museum is thereby used as a solo experience for those seeking quiet moments of reflection, introspection, inspiration, or pleasure. It is used also as a social space to share with others. Students, faculty, and community members saw the campus art museum as a place to take family or friends, as exemplified by this undergraduate's comment:

I feel like I evangelize when I'm in the museum. I tend to bring everyone here. If someone wants to meet up for coffee, I say, "Hey, we should just go to the art museum because it's free"...I've met blind dates here because it's a safe space and the guards know me....I bring my family every time they come to town. (Personal communication, March 16, 2011)

The museum is thus a venue that some people seek out and make frequent use of, taking others with them from time to time. Nonetheless, museum personnel and students on all the campuses talked about the challenge of getting students and faculty, particularly those in disciplines other than the arts, to come to the museum. Museum staff, student groups, and community associations all work to create and host social events to entice others "in the door," so that they may connect in some way with art.

\section{Engaging Through Social Events}

March. Not yet warm, but yellow-green leaves are beginning to outline bare branches of trees. At the University of Missouri's Museum of Art and Archaeology, people are setting up "Art in Bloom," an annual event where local florists and garden club members create flower arrangements inspired by a work of art in the museum. I was in the director's basement office when I looked out the high windows and saw, wheeling by, an arrangement so large that two carts had been tied together. On opening night, children to the elderly filled the museum and strolled from room to room to look at the flower arrangements paired with works of art. Along with a description of each floral entry and the accompanying art piece, visitors receive a ballot so they can vote on favorites in various categories that ingeniously guided viewers to think about the color, texture, and movement of the floral arrangements and the works of art. (Field notes, March 18, 2011) 


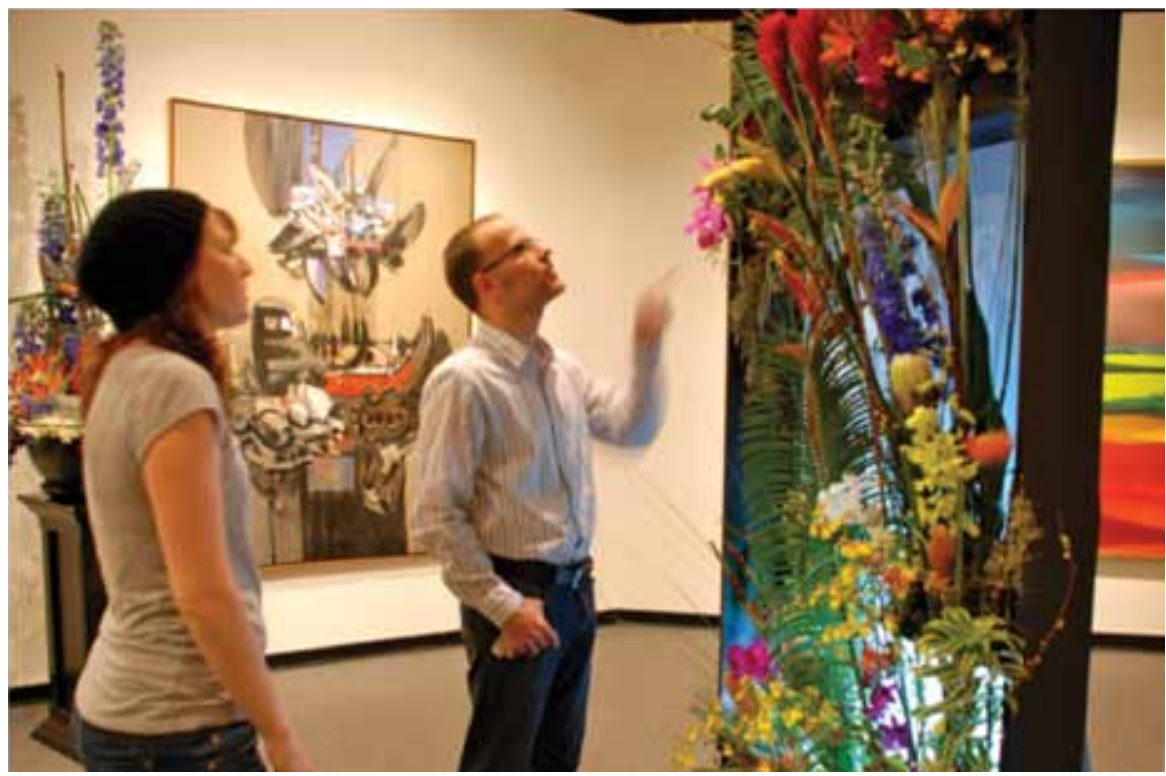

Fig. 3: Art in bloom

Social events are organized with the hope of linking an event with a visit to the galleries. Some social events, such as exhibition openings, lectures, and artist demonstrations, are free. Others, such as art auctions or banquets, are fund-raisers. Allen After Hours is popular in Oberlin where once a month the museum opens its doors in the evening. Music (often played by Oberlin Conservatory students) and food accompany a planned event, such as an artist demonstration or talk. The Snite Museum of Art creates special programs on football Saturdays, making the museum part of the tailgate parties by welcoming students, parents, and alumni returning for games at Notre Dame. The College of Arts and Letters collaborates with the Snite and provides Saturday Scholars lectures at noon in the museum on football Saturdays. At the University of Chicago, Sketching at the Smart is an ongoing program coordinated by the David and Alfred Smart Museum in conjunction with the studio and visual arts departments. Once a quarter, the Smart hires a model to pose in the lobby of the museum and invites students, staff, and community members to come and sketch. The museum provides paper and other art-making supplies and graduate students in the Department of Visual Art provide instruction, if desired.

Social events directed towards students tend to have one thing in common: food. Some events are creative innovations of a particular place, but ideas that work spread quickly. For example, the Smart holds Study at the Smart right before finals, a suggestion by a faculty member, as described by Smart personnel: 
We were trying to think of ways to engage UC students, their dorms are right here. You can throw a rock and break a window but students don't come to the museum for public programs.... They don't really come to hang out and just have fun or relax because the degree programs are very rigorous here. So he, half-jokingly, said, "You should just have a study program because all the students do is spend time at the library anyway." UC has this moniker "Where fun goes to die," so we decided to have a study program and keep the museum open until $1 \mathrm{AM}$ at the start of reading period and just set up tables and power strips for computers and have free coffee and food and see what happens. (Personal communication, November 9, 2010)

On the evening of Study at the Smart, the museum opens to students at nine in the evening and the students are ready. One museum staff member stated, "They are waiting outside the door and then they camp out. They are sprawled on the floors of the galleries, they take off their shoes... It's a social thing and it's a motivating thing for them to get organized for reading period and it's a space that's different from the library" (Personal communication, November 9, 2010). At 11 p.m., trays of food are set out in the lobby for a study break. Students who might never come to the museum otherwise come to Study at the Smart. The Spencer Museum has also begun a study night event during finals. Their academic director "got the ball rolling" and she happens to have studied at the University of Chicago. Students and the museums work together to attract campus students to the museums, hoping they will feel comfortable there, see things of interest, and return on their own.

Possibly the most popular program that informally engages students across disciplines in art appreciation is the Art Rental Program at the Allen Memorial Art Museum (2011) at Oberlin College. An assistant curator stated, "I was over at a friend's house last night-she's a senior, has her own off-campus house, and she had a Picasso in the living room" (Personal communication, September 29, 2010). The student had the Picasso as part of the Art Rental Program. The tradition began over 70 years ago. Students rent at a nominal fee $(\$ 5)$ a work of art for a semester from an art rental collection of nearly 400 objects (Allen Memorial Art Museum, 2011). Students begin camping out the night before rental begins, as museum staff described, "It's interesting to watch students...some of the people who camp out, they just like really get into the thrill of it and they aren't necessarily the people who know a lot about the art or get that excited about art otherwise, but they feel passionate about this" (Personal communication, September 29, 2010). An art history professor added, 
The kids slept out on the sidewalk over night and they ran out of pieces. There is this intensity here which really makes it wonderful.... There's nothing that compares to the primacy of the actual object....It is magical... and the kids just thrive on that. (Personal communication, September 29, 2010)

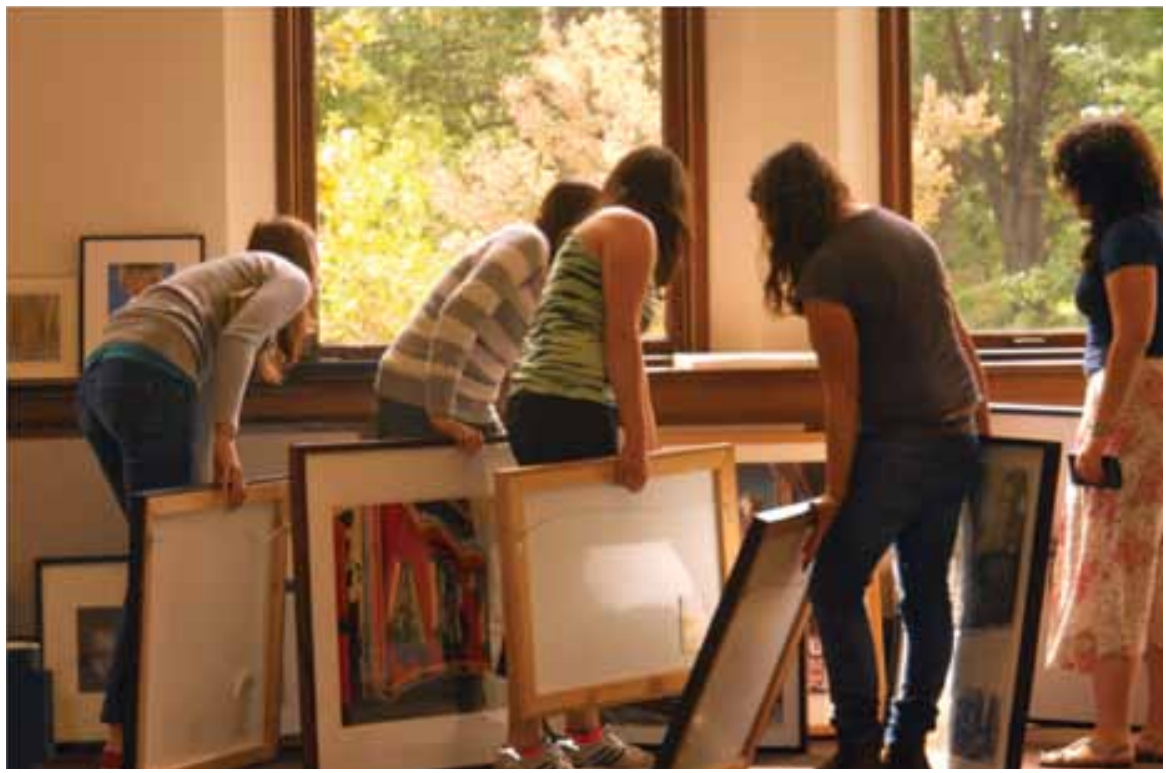

Fig. 3: Art in bloom

An undergraduate stated that the ability to "have the art in your apartment takes away from that stigma of art being like something that can only be understood or enjoyed by the elite" (Personal communication, September 30, 2010). The art rental collection is not a compilation of the least valuable works in the museum, but rather a range of works by well-known to lesser-known artists. Each semester some lucky student gets to hang a Picasso or a Toulouse-Lautrec on her or his apartment wall, and in the process, informally learns about art and art appreciation.

\section{Learning Through Work}

Work experiences at the museum are helping students decide on majors or careers. Some work for wages; some obtain units of credit in return for labor; and some have fellowships and receive a stipend plus tuition and fee waivers. As a rule, all more than enjoy their work at the museum, they are enthusiastic. The following quotation is an example: 
The reason I am here at the art museum is that my parents, when I was a freshman coming here to the University of Arizona, they said "you need to get a job before you get there." So I...started looking online and they had a posting for the business office, sort of an assistant... and I got the job... A little bit into my job, I got asked to help with an exhibition and I said, "sure." And now I'm kind of all over the place. I help with exhibitions and with the business office too, so my new title is curatorial museum assistant... It's fun to know the process of how art goes up on the wall and to, you know, very carefully measure everything and you'll be standing there and the curator will ask, even us, the students, "Does this look okay? What do you think about this? Will you look at this? When you walk in, how do you feel?" It's really cool to be part of that. I've been a part of every tiny little thing in the museum... I've spent lots of time here and am very happy here. (Undergraduate student, personal communication, January 26, 2011)

Through hands-on learning, students become familiar with planning and preparing exhibition space, curating a show, writing labels, handling and storing art, record keeping, provenance research, leading tours and educating others about art, and security concerns; in other words, with the many tasks associated with running an art museum. The work often changes, giving students multiple museum experiences. An interesting paradox is that some of the museums with the fewest resources rely heavily on students' input and work to remain active. As a result, those students appear to receive even more responsibility and experiences in museum work than in museums with more resources.

\section{How People Become Interested in Art and Art Museums}

Not everyone is attracted to the visual arts. Why do some become interested? What happens that they not only become enamored with visual art but also, perhaps, choose a career that allows them to be immersed in art or museum life? From this study, four factors seem to have the greatest influence: experiences with art growing up, experiences visiting art museums, a course or courses, and work in an art museum or gallery.

Often, a combination of these factors coalesced to encourage study participants to pursue studies, work, and/or frequent interactions with art and museums. 
One led to another as when growing up in an art-centered environment set the stage for taking courses in studio art and/or art history which culminated in a degree in the arts and subsequent arts-based work. Growing up in an environment where people make art or appreciate various forms of art helps greatly to set the context for being associated with art throughout one's life. About a third of respondents reported this as their primary reason for involvement in the arts and art museums.

Visits to art museums tend to be part of growing up in an environment friendly to the arts, but sometimes museum interactions took place later on and were particularly meaningful for the individual. The art museum was especially important as a means for engaging faculty, administrators, and alumni who had not pursued studies or careers in visual arts. For many in this group, their prior interactions with art museums made them want to share the experience. They made use of the art museum in their classes and supported the campus art museum in various ways.

A course (generally an art history course) that a student just happened to take to fulfill liberal arts and humanities requirements or signed up for because it was receiving rave reviews from other students worked to interest others in art and art museums. This group had not necessarily received early socialization into the arts.

Yet others found their niche or at least expanded their interest in art and art museums through work or internships with museums. Some in this group knew nothing about art and art museums before getting a job with a museum; others were interested in art or art history but became more intrigued with museums through their work and decided to pursue museum careers. People, therefore, become interested in art and art museums through several different paths, often through experiential means, rather than formal education. How do they talk about what that interest means for their lives?

\section{Art Talk: How People Speak of the Role of Art and Art Museums in Their Lives}

I love it when I hear a college student say, "I had no idea art spoke like this." (Curator of Education, personal communication, November 3, 2010)

The words captured, inspired, spoke, struck, and fell in love often appear in interviewees' transcripts. They remember being struck by some work of art, stopped 
in their tracks, virtually unable to move. They talk about ways in which museum objects inspire them in their own art endeavors or in life in general. They reflect upon art that helps them make connections, that allows ideas, thoughts, or plans to click into place. A few spoke of personal revelations. Respondents also found it difficult to fully express what art had meant for them, not because it was without meaning, but because art is a different language and that is, perhaps, the source of its strongest impact. As a different language, it allows other ways of viewing the world, other ways of being in the world.

Many respondents have vivid memories of being caught by a particular painting or museum exhibition, affected deeply, and sometimes set on a course for further explorations of and experiences with visual arts, as in the following account:

When I was twelve, my mother and father took us all to Europe and I remember the moment where everybody else was sort of going through, "Ok, we've seen this and we've seen this," and I'm dead stuck in front of a Degas drawing. I have this incredible awareness of the pastels... and the paper and that creative imagination, that creative expression, merging... And, I have to say, I was never the same. I knew... this was a place for me to find myself, this art world place, and worlds within worlds, and that has never left me. In hard times and good times, I can still find myself there. ...Visual Arts started there for me, twelve years old, in the Louvre. (Campus art museum director, personal communication, March 17, 2011)

Sometimes such moments were matched with serendipity. The emotions evoked by art brought clearly to the forefront something one wanted to pursue, as for this woman who became a docent for a campus art museum:

I was in the art institute in Chicago and said, "I could just stay here for the rest of my life." ... It was like a wish. And I said, "Oh, I just wish I could stay here." And when I got back to Bloomington, there was a thing in the paper about becoming a docent and doing a lot of stuff in the museum, and that was that. (Personal communication, November 5, 2010)

For others, their interest in art grew slowly until multiple experiences culminated in a realization of the role it could play in their lives. A student at Indiana University described how she came to her decision to major in art education. 
I wouldn't say I grew up with the arts in my life. My parents-we definitely went to museums, but it was always something that was boring, you know, but I think still that instilled a creative side from those experiences.... it took me a while to realize what I wanted to do. I knew that I wanted to work with people.... I went to psychology for a little bit, I went to sociology and I took a few art history courses and I think my "ah ha" moment was realizing that art can affect people.... My interest is more in art education and using art to expand people's world, to have a more open mind through art... (Personal communication, November 4, 2010)

Respondents talked about the power of art to move them and to cause them to see differently. A student security guard described a Rothko, her favorite work in the campus art museum, as "a feeling that is painted rather than an image, a subconscious feeling" (Personal communication, January 26, 2011). A math senior who had helped create an exhibit on math and art, said:

I don't think I could ever look at some things the same way again. I'm taking an art history course now. Art is like math. It is all structure and patterns. Math and art describe the abstract. I couldn't have told you that a year ago. This work has really shaped my worldview. Things take on new forms. (Personal communication, January 26, 2011)

Art is a language that can be sensual, emotional, and analytical.

\section{Influences and Impacts of Campus Art Museums}

The student quoted at the end of the previous section was part of a team of three math students and curator who produced an exhibition at the University of Arizona Museum of Art, called The Aesthetic Code: Unraveling the Secrets of Art. It developed, as described by the curator:

I wanted to do an exhibition on math and art....I thought it would be really interesting and we could talk about the golden ratio and fractals and all this stuff that honestly I didn't personally understand when I first started... I called up the person who is in charge of the listserv in the math department and I said... "Put in there that I'm looking for math students who are interested in art to come and mathematically analyze works in our collection...." 
And so I got these three students.... We were definitely the blind leading the blind at first. We didn't know what we would find and ... after a while we sort of trained our own eyes and got really good at seeing them right away, which pieces would have relationships that we could utilize and talk about. ...We started with the hardest parts, we started with golden ratio and color and optics and fractals. We started at the high level and one day I had this epiphany because I was having trouble pulling it all together, "oh, we have to start with line...." (Personal communication, January 25, 2011)

The exhibition explored mathematic and design principles that artists have used for centuries. Combing through works from the museum's collection, the students and curator chose art appropriate for demonstrating each concept from line to tessellations. The accompanying text was crafted to explain the concepts to someone not necessarily familiar with either art or math. Students who had never visited the museum before attended the talk by one of the math students and a math professor. Public school and university teachers used the exhibition in classes. The exhibition also provided a compelling forum for informal learning.

In addition to their significant contribution to courses and research, campus art museums affect people in their everyday lives and, consequently, their institutions. For some, the campus art museum was a deciding factor in their decision to attend a particular school or to accept a position. One student reflected on the role of the Snite in her attraction to Notre Dame:

Actually I had never visited the art department before I was accepted. I came here for conferences related to art... and I came to the Snite on both occasions because I usually gravitate towards museums wherever I go. I was incredibly impressed with the collection. I was expecting it to be very small and unimpressive-university museums don't have to be that large, so when I saw it, I was very impressed. So when I was accepted, that was definitely something that factored into my decision. (Personal communication, November 10, 2010)

A studio arts professor also was impressed by the Snite during her employment interview:

I was aware of the museum when I came here because of the pre-Columbian collection. That really interested me... I was actually kind of blown away when I...saw it. Part of the interview was to visit the museum - it was part of 
everything the university could offer. (Personal communication, November 10, 2010)

Might this student and professor have gone to Notre Dame if the campus had no art museum? Professors at several institutions said that since faculty positions are difficult to find, they most likely would have gone somewhere without a museum, if that were the only choice available, but that they are happy to be at schools with museums with extensive collections. Students, however, have more choices about which institution to attend and those who already have an interest in art history, museum studies, or arts in general are likely to opt, if they can, for a school with a good art museum.

The influence of art museums on helping to determine students' careers is significant. "I probably wouldn't have realized I wanted to have a career in the arts if it hadn't been for the museum. It has helped me discover what I want to do," stated an Indiana University student (Personal communication, November 4, 2010). Others made similar comments. This impact most often comes through the opportunity for students to work at the museum. Some students who begin their studies planning to become art history professors or studio artists discover, through jobs at the museum, that they want a career with museums. Some students from non-visual arts disciplines learn through work at museums that they want to pursue museum studies. Some students from across the disciplines who have the opportunity to be docents for public school groups or to work with children through museum education programs, decide that they want to continue working in museum education.

Students who worked at the museums talked about how they felt "privileged" to have intimate contact with art and access to programs and speakers. That the museums' collections included works by famous artists and ranged over extensive periods of history and cultures gave students a sense of pride in the museums, as well as in the institutions they attended. "You really care about what's here," stated a University of Arizona student (Personal communication, January 26, 2011). Another student, talking about the Allen Memorial Art Museum, said, "It gives us a certain amount of pride and ownership. It's our Monet. It makes me proud to go to Oberlin" (Personal communication, September 30, 2010).

Interaction with art and art museums can influence future avocations of students. A 1958 science graduate became interested in art through a class. As a hobby, he became an art collector and later a donor to his campus art museum, created an endowed fund for collecting contemporary works, and was serving on the museum's advisory committee. 
The campus art museum may also affect visitors' perspectives, identities, and emotions. Many talked about how being around art and creativity made them "happy" or how just being in the museum was peaceful, and even if working in the museum, they found the job relaxing. A recent survey of over 50,000 adults in Norway observed that people who engage in artistic activities or partake in "receptive" cultural activities such as visiting museums and the theater feel in better health and enjoy life more than people who do not (Cuypers et al., 2011). A museum director mentioned a visiting speaker who addressed museums' contributions to well-being:

One of the things she pointed out was that medical studies have been done where people inside museums exhibit lower blood pressure and the lessening of stress because they recognize museums as sort of sacred and safe places and respected places, good places to be. (Personal communication, November 3, 2010)

The impact of art museums that resonated most with me, however, was how standing in front of a Degas or Rothko or Giovanni Bernardi rendered the viewer "dead stuck" as the art lit a spark of creativity deep within, that spark of profound imagining that enlivens and changes lives. I have spent my life as an educator and am distressed by current emphases on test scores and technical skills that push the arts to the sidelines, or eliminate them altogether. The art museums I visited were working to counterbalance this technocratic impulse. I agree with an art history professor who stated, "Art is one of the fundamental things that defines the human experience and the human condition." He continued:

the urge to create, the urge to respond to the world around us through imagery, through colors, through space, and when it is done at a high level... it is profoundly moving and exulting and enriching. It enriches life. It can give us pleasure, it can also disturb us..., it can cause us to see the world in different ways. It can bring us to experiences and emotions that we haven't had before.... Anything you can think of in the world is transformed through art and given back to you in a way you never thought of before. And sort of turn this around. When you look at a Sudlow ${ }^{3}$ landscape....and then you go drive through the country, you see it a different way because Sudlow taught you to see it. (Personal communication, March 16, 2011)

Many sorts of interactions are taking place in campus art museums, resulting not only in sites of learning, but also in locations of connection, creativity, inspiration, and deep pleasure. 
Duncan Cameron (1971/2004) in The Museum: A Temple or a Forum, states that many museums cannot decide whether they want to remain a temple or become a forum for "confrontation and experimentation." Temple and forum were not metaphors generally used by study participants. They are useful, however, for describing how, increasingly, the perception and role of the campus art museum is changing. As a temple, the museum holds precious gems and people make pilgrimages to stand before great works of art. As a forum, the museum is a catalyst for various kinds of interactions that might be more like a laboratory for the mixing of people and ideas. The thriving campus art museum is one that embraces its role as facilitator for all kinds of dialogues, research, performances, exhibitions, and experiences. It welcomes diverse and interdisciplinary perspectives. It sees its role as serving a population much broader than the arts community and it seeks to make a difference not only in the academic lives of students and faculty but also in their day-to-day lives.

\section{Notes}

1. The seven art museums include: Indiana University Art Museum, Snite Museum of Art (University of Notre Dame), Allen Memorial Art Museum (Oberlin College), University of Arizona Museum of Art, David and Alfred Smart Museum (University of Chicago), Spencer Museum of Art (University of Kansas), and University of Missouri Museum of Art and Archaeology.

2. In the 1950s and 1960s, the Kress Foundation donated works of primarily Italian Renaissance art to 18 regional art galleries and 23 college and university art museums. The gifting to academic art museums was known as the Kress "Study Collection Program" and involved more than 200 paintings, many of them old masters, sculptures, and other objects (History of the Kress Collection, n.d.).

3. Robert Sudlow (1920-2010) was a landscape painter who taught in the College of Fine Arts at the University of Kansas. 


\section{References}

Allen Memorial Art Museum. (2011). Art rental. Retrieved March 26, 2012, from http:// www.oberlin.edu/amam/artrent.html

Cameron, D. F. (2004). The Museum, a Temple or the Forum. In G. Anderson (Ed.), Reinventing the museum: Historical and contemporary perspectives in the paradigm shift ( $\mathrm{pp}$. 61-73). New York: AltaMira. (Originally published 1971)

Cuypers, K., Krokstad, S., Holmen, T.L., Knudtsen, M.S., Bygren, L.O., \& Holmen, J. (2011). Patterns of receptive and creative cultural activities and their association with perceived health, anxiety, depression and satisfaction with life among adults: the HUNT study, Norway. Journal of Epidemiology and Community Health, May 23. Retrieved March 26, 2012 from http:// jech.bmj.com/content/early/2011/05/04/ jech.2010.113571
Goethals, M., \& Fabing, S. (2007). College and university art museum program summary report. Andrew W. Mellon Foundation. Retrieved March 26, 2012, from http:// mac.mellon.org/CUAM/cuam_report.pdf

History of the Kress Collection. (n.d.). Retrieved March 26, 2012, from http://www.kressfoundation.org/collection/default.aspx?i $\mathrm{d}=70 \&$ terms $=$ study+collections

Russell, J., \& Spencer, T. (Eds). (2000). Art on campus: The college art association's official guide to American college and university art museums and exhibition galleries. Monkton, MD: Friar's Lantern, Inc.

Villeneuve, P. (Ed). (2007). From periphery to center: Art museum education in the 21st century. Reston, VA: National Art Education Association.

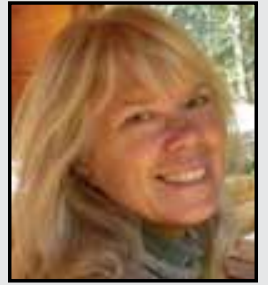

Corrine Glesne is a qualitative researcher and educational anthropologist, and the author of Becoming Qualitative Researchers $(2011$, 4th ed.). Previously, a professor at the University of Vermont, she currently lives in Asheville, NC and does independent teaching and research. She spent 2011 investigating ways in which campus art museums are integrated into university and college life for the Samuel H. Kress Foundation.

\section{LINKTO:}

http://www.kressfoundation.org 